\title{
The State Financial System as a Main Element of Implementing Regional Government in The Unitary State
}

\author{
Mas Iman Kusnandar ${ }^{1 *}$, Refi Pratiwi ${ }^{2}$ \\ ${ }^{1 * 2}$ University of Sultan Ageng Tirtayasa, Indonesia \\ Corresponding Author: drmasimankusnandar@gmail.com ${ }^{1 *}$
}

Keywords : Unitary State; Authority;

Planning Systems and Budget Principles

\begin{abstract}
:
The basis and objectives of the state are contained in the Constitution as stated in the Preambule of the 1945 Constitution of the Republic of Indonesia To make it happen, it is necessary, among others, to support an integrated budgeting system through fiscal policy, so it can be formulated, First, how to realize the correlation of budget principles to the planning system which includes programs and activities of local governments. Second, why is regional financial management $a$ subsystem of the state financial system, and the main elements of local government administration. This study is a qualitative research method through a normative juridical approach and empirical analysis. Research result; First, the Regional Revenue and Expenditure Budget is an integrated budgeting principle that is integrated with the regional government planning system; Second, the success of local government administration is largely determined by an integrated system in the management of regional finances as a subsystem of state finance in the form of a unitary state.
\end{abstract}




\section{Introduction}

A country can exist with several criteria including the Kingdom or the Republic. In the form of a unitary or union, the state has the basis and objectives set out in the constitution. The State of Indonesia is a country that adheres to a Unity in the form of a Republic. This is stated in Article 1 paragraph (1) of the 1945 Constitution of the Republic of Indonesia. It aims to protect and promote public welfare and the intellectual life of the nation, and to participate in implementing world order based on Pancasila, as stated in the opening of the 1945 Constitution of the Republic of Indonesia.

The principle of democracy emphasizes the existence of public involvement in the process of forming laws and regulations (rechts varming). With democracy in the sense of the mechanism for the formation of laws and regulations, it shows the existence of public participation. This means that the people are directly involved in providing suggestions and opinions in the context of the formation of Regional Regulations (Akmal Boediyanto: 2010).

In the view of democracy, the people have the right to express their opinions and aspirations for the implementation of good governance, because this is a form of embodiment of the people's sovereignty. A democratic state prioritizes aspects of participation, transparency (openness), accountability (responsibility) and justice (balance) in managing the government, including in the formation of Regional Regulations.

The form of a unitary state has inherent characteristics, namely the supremacy of control parliement and the absence of subsidiary sovereign bodies. A unitary state is a state that is not composed of several states, but rather a single state. This means that there is only one state and no state within a state. In a unitary state there is only one government, namely the central government, which has the highest authority. In the administration of government using the principle of centralization or decentralization. The application of decentralization has several principles which consist of three forms, namely: a.) Territorial decentralization, namely the transfer of authority given by the government to public bodies (oppenbaar lichaan) such as self-governing alliances (zelf regende gemmenchappen), in the form of organs that manage and regulate the interests of the public. common in a certain area. The transfer of authority results in the general body or organ receiving autonomy; b.) Functional decentralization (including according to service/interest), namely the delegation of authority to regulate and administer certain regional government functions by a functionally separate organ or organization; and c.) Administrative decentralization (also known as deconcentration or ambtleyk), namely the decentralization of authority to carry out the tasks of the central government in administering government in the regions by the regional officials themselves (Rauf Alaudin Said: 2015).

The regional government in its administration is based on the principle of decentralization, and the principle of regional autonomy and auxiliary tasks in the form of delegation of affairs, delegation of authority and finances, and managing their own household affairs, as regulated in Article 1 paragraph (1), Article 18, paragraph (1), Article 18A paragraph (1) and paragraph (2) of the 1945 Constitution of the Republic of Indonesia, Law Number 17 of 2003 concerning State Finances, Law Number 25 of 2004 concerning the National 
Development Planning System, Law Number 23 of 20032014 concerning Regional Government and its Amendments, and Law Number 30 of 2014 concerning Government Administration, and Government Regulation Number 12 of 2019 concerning Regional Financial Management.

Government affairs consist of 3 affairs, namely:

- Absolute government affairs which are the affairs of the central government; o Foreign Affairs

o Defense and Security Affairs

o National Monetary and Fiscal Affairs

o Judicial Affairs

o Religious Affairs

- Concurrent Government Affairs, namely affairs that are divided into those of the Central government; provincial government; and district/city governments. Regulated in laws and regulations

- General government affairs, namely affairs that cannot be carried out by the provincial government and district/city governments, and are residual.

The central government in a unitary state has the highest power and authority because there is no state within the state, there is only a government structure, namely the central government and regional governments including the provincial government and district/city governments. To carry out concurrent government affairs, it is necessary that the authorities consist of:

- Attribution Authority, namely the granting of government authority by lawmakers to government organs. Based on Law Number 30 of 2014 concerning Government Administration (Government Administration Law), Attribution is the granting of Authority to Government Agencies and/or Officials by the 1945 Constitution of the Republic of Indonesia or the Act.

- Delegation authority, namely the delegation of government authority from one government organ to another. Based on the Government Administration Law, delegation is the delegation of Authority from a higher Government Agency and/or Official to a lower Government Agency and/or Official with responsibility and accountability fully transferred to the recipient of the delegation; and Mandate authority is the authority on assignment orders from higher officials to lower officials, the responsibility of which is on those who give the authority.

Authority is the basis for carrying out those related, among others, to planning and budgeting activities. Planning activities can be carried out by means of Top Down Planning and Bottom up Planning. Planning so that it can be carried out continuously from one period to the next, in the substance of planning the most important thing is to contain rational programs and activities so that they can be accounted for. as a basis for planning, besides that the planning product must be determined by laws and regulations to ensure that the planning can be sustainable so that the targets and targets to be achieved become clear. The plans 
made must be arranged in a system, meaning that there is a hierarchical relationship between general/national planning and special/regional planning in order to avoid overlapping programs and activities so that the planning is efficient; economical; and effectively included in the preparation of the budget must be based on the planning system.

Planning and budgeting is carried out on a performance-based, medium-term, and integrated basis, which is the embodiment of the three principles of public financial management, namely; (1) The Medium Term Fiscal Framework which is implemented consistently (aggregate fiscal discipline); (2) Allocation on priorities to achieve the greatest benefit from limited funds (Alocative Efficiency), namely through the application of the Medium Term Expenditure Framework which consists of the application of Forward Estimates, performance based budgeting ) and a unified budget (Unified Budget); and (3) efficiency in implementation by minimizing costs to achieve the set targets (Technical and Operational Efficiency) (Ministry of Finance and Bappenas, 2009).

The principle of budgeting in state budgeting uses the Unfield Budgeting Principle in order to achieve synchronization of various government policies so that it does not cause overlapping of the implementation of programs and activities carried out by the central government and regional governments, all of which refer to the planning system.

The state financial system includes the management of regional finance which is its subsystem. Financial management is realized in the revenue and expenditure budget system at the central level as outlined in the state revenue and expenditure budget system established by law for the central level while at the regional level it is stated in the regional revenue and expenditure budget system determined by regional regulations.

Regional financial management is manifested in a regional revenue and expenditure budget system that includes regional government programs and activities in the context of realizing short-term/annual development plans. As a stage in the implementation of the medium-term development plan that refers to the regional long-term development plan. In medium-term projections, the level of uncertainty in the availability of future budget allocations can be reduced both in terms of providing funding needs to finance the implementation of various new priority policy initiatives and to ensure the sustainability of ongoing priorities (on going policies), so that policy designers can present budget planning. which is oriented towards the achievement of targets in a complete, comprehensive, and appropriate context in accordance with the established policy planning framework. By focusing on priority policies that can be financed, achieving fiscal discipline which is the key to the effective use of public resources, it is hoped that government accountability in macro fiscal administration can be achieved (Ministry of Finance and Bappenas, 2009).

The problem faced is the correlation of the principle of budgeting to the development planning system which includes the short, medium and long term. In the greeting, it contains programs and activities in the context of implementing local government, so from these problems it can be formulated as follows;

- How to realize the correlation of budget principles to the planning system which includes local government programs and activities? 
- Why is the regional financial system a subsystem of state finances, and the main elements of the administration of regional government in a unitary state?

\section{Research Method}

The research method used is a qualitative method through a normative juridical approach and empirical analysis. Normative juridical research is a legal research method carried out by examining library materials or mere secondary materials (Amrudin and Zainal: 2004).

Normative Jurisdiction is intended to strengthen the planning system and budgeting principles based on the respective juridical basis of the 1945 Constitution of the Republic of Indonesia; Law Number 17 of 2003 concerning State Finances; and Law Number 25 of 2004 concerning the National Development Planning System; Law Number 23 of 2014 concerning Regional Government; Law Number 30 of 2014 concerning Government Administration; and Government Regulation Number 12 of 2019 concerning Regional Financial Management.

Form of State and Government; The unitary state has the inherent characteristic of the supremacy of the central parliament, and the absence of subsidiary sovereign bodies, that the unitary state is not composed of several countries but that the state is single in nature, there is only one state, and in it there is only one government, namely the central government which has the highest power and authority in all fields of government which at the last and highest level can decide everything in the country based on its constitution, the implementation of which is further regulated in laws and regulations, and in certain situations and in compelling circumstances can form government regulations in lieu of law. The unitary state can be in the form of a monarchy or republic, the principle of government can be centralized or decentralized, the system of government is presidential or parliamentary. The State of Indonesia in the 1945 Constitution of the Republic of Indonesia, article 1, paragraph (1) the State of Indonesia is a unitary state in the form of a republic (Hestu Cipto Handoyo: 2003).

Furthermore, the State Government in article 4, paragraph (1) the President of the Republic of Indonesia holds the power of government according to the Constitution, and in article 18, paragraph (1) the Unitary State of the Republic of Indonesia is divided into provincial areas and the province is divided into districts and cities, which each province, district and city has a regional government, which is regulated by law. Regional Government based on Law Number 23 of 2014 concerning Regional Government, article 1, paragraph (1) Regional Government is the implementation of government affairs by regional governments and regional people's representatives according to the principle of autonomy and assistance tasks with the principle of autonomy as wide as possible in the system and principles of the State Unity of the Republic of Indonesia as referred to in the 1945 Constitution of the Republic of Indonesia. Based on theoretical explanations; the 1945 Constitution of the Republic of Indonesia; and the Law of the Republic of Indonesia Number 23 of 2014 concerning Regional Government that the Regional Government is subordinated to the State Government, namely the Central Government. 
Relationship of Government Authority between the central government and regional government as stipulated in the 1945 Constitution of the Republic of Indonesia, article $18 \mathrm{~A}$, paragraph (1) The relationship of authority between the central government and regional governments of provinces, regencies, and cities, or provinces and regencies and cities regulated by law with due observance of regional specificity and diversity; and Law Number 30 of 2014 concerning Government Administration, CHAPTER V government authorities, article 8, paragraph (2) Government agencies and/or officials in exercising their powers based on: a. laws and regulations; and b. General principles of Good Governance; Article 11 Authority is obtained through Attribution, Delegation, and/or Mandate; Article 17, paragraph (1) Government agencies and/or officials are prohibited from abusing their authority; Article (2) Prohibition of abuse of authority as referred to in paragraph (1) includes: a. prohibition of exceeding the Authority; b. prohibition of mixing Authority; and/or c. prohibition of acting arbitrarily.

The planning system, as regulated in Law Number 25 of 2004 concerning the National Development Planning System, among others regulates the Regional Spatial Plan (RTRW) and the Long-Term and Medium-Term Development Plan (RPJP) and (RPJM) at the Central level. while in the regions it is determined by regional regulations. While the short-term development plan is contained in the government activity plan (RKP) and the regional government activity plan (RKPD) as guidelines for the preparation of the State/Regional revenue and expenditure budget, the APBN is stipulated by law, while the APBD is stipulated by regional regulations, including all implementing regulations. in accordance with the hierarchy of laws and regulations.

The Budget Principle, using the Unfield Budgeting Principle as stated in the 1945 Constitution of the Republic of Indonesia, Article 18 A paragraph (2) Financial relations, public services, utilization of natural resources and other resources between the central government and local governments are regulated and implemented fairly and in harmony based on the law, and is described in Law Number 17 of 2003 Article 6, paragraph (1) the President as head of government holds the power to manage State finances as part of government power; paragraph (2) The power as referred to in paragraph (1) letter c. submitted to the governor/regent/mayor as the head of regional government to manage regional finances and represent regional governments in the ownership of separated regional assets, and article 22, paragraph (1) the Central Government allocates balancing funds to regional governments based on the central financial balance law and area.

While the empirical analysis is intended to analyze all documents of the Planning system which includes the Regional Spatial Plan (RTRW); Regional Long-Term Development Plan (RPJPD); Regional Medium Term Development Plan (RPJMD); Regional Government Activity Plans (RKPD), and the Unfield Budgeting Principle in a hierarchical manner that regional financial management is a subsystem of the State financial system which is manifested in the relationship between $A P B D$ and $A P B N$, and at the same time that regional financial management is a key element in the administration of regional government because it contains programs and activities that lead to indicators of regional government performance 
achievements within a period of 1 (one) year from January 1 to December 31 . Is there a correlation between the Financial Statements of BPK RI examination results with the Government Agency Accountability System (SAKIP) whose assessment is carried out by the KemenPAN-RB has an impact on the Human Development Index (IPM) and Regional Competitiveness Index (IDSD), this is the basis for assessing the success of governance Area.

\section{Result and Discussion}

Based on the description above, the results and discussion are as follows:

\section{Efforts to Realize the Correlation of Budget Principles to the Planning System in which Include Regional Government Programs and Activities}

The preparation of regional revenue and expenditure budgets uses the unfield budgeting principle in order to achieve the integration of various government policies (Central Government Policy; Provincial Government, and Regency/City Governments) and does not cause overlapping of regional government programs and activities documented in the Plan. Government Activities (RKP) at the Central Government level, and Local Government Activity Plans (RKPD) at the local government level guided by the national/regional medium-term development plan which is the elaboration of the national/regional long-term development plan. The preparation of the state/regional revenue and expenditure budget is carried out through the stages of preparing and determining the budget; budget implementation and administration; accountability for budget implementation as follows:

\section{1.) Planning}

Planning can be done in two ways, namely Bottom up Planning and Top Down Planning. Bottom up Planning through the mechanism of development planning deliberation (Musrengbang) in stages starting from village, sub-district, city district, province and national. Meanwhile, Top Down Planning through the elaboration of the strategic plans of the ministries/agencies/regional apparatus organizations which is the elaboration of the National/Regional medium-term development plans, its activities are carried out in the development plan deliberation forum at the level of ministries/agencies/regional pernagkat organizations. The result is a work plan for the Ministry/Agency/Regional Apparatus Organization.

The results of the two development planning patterns are compiled into a government work plan (RKP) at the central government level, and a regional government work plan which includes programs and activities. The RKP/RKPD is the basis for the preparation of the budget to subsequently become the budget activity plan (RKA).

\section{2.) Preparation Budgeting}

The preparation of the regional budget activity plan from the preparation of the Government Activity Plan (RKP) / Regional Government Activity Plan (RKPD) is intended to determine the financing capability contained in the provisional budget ceiling priority (PPAS) as a memorandum of agreement between the central / regional government and 
the House of Representatives / Regional People's Representative Assembly. Furthermore, it is poured into the general policy of the provisional budget ceiling priority budget.

According to the provisions of Law Number 12 of 2019 concerning Provisional Budget Priorities and Ceilings, hereinafter abbreviated as PPAS, are priority programs and the maximum budget limit given to regional apparatus for each program and activity as a reference in the preparation of work plans and budgets for regional work units (RKA). SKPD). The Budget Implementation Document for the Regional Apparatus Unit (RKASKPD), hereinafter abbreviated as DPASKPD, is a document containing the income, expenditure and financing of the SKPD that carries out the function of the regional general treasurer which is used as the basis for implementation by budget users.

Government Activity Plans (RKP) / Regional Government Activity Plans (RKPD) and PPAS general budget policies to subsequently become the basis for the preparation of the Budget Activity Plan (RKA) as the basis for preparing the Draft State/Regional Revenue and Expenditure Budget (RAPBN/APBD). Furthermore, it is discussed jointly between the government/regional government and the House of Representatives /Regional based on the Rules of the House of Representatives/Regional People's Representative Council.

\section{3.) Budgeting}

Budgeting begins with changes to the budget through the procedures and mechanisms of the House of Representatives/Regional. The stages are as follows:

- Submission of RAPBN/D by the government/Local Government

- General views of the House of Representatives/Regional

- Government/Local Government Answers

- Discussion with the government/local government with the People's/Regional House of Representatives

- The approval of the House of Representatives/Regional House of Representatives begins with the final word of the faction of the House of Representatives/Regional then a mutual agreement.

- Determination of APBN/D with Laws/Regional Regulations

\section{4.) Implementation and Administration Budgeting}

a. Implementing Budgetiing

Before implementing the APBN/D, a budget translation is carried out in the form of a budget implementation document (DPA). The elaboration is stipulated by a presidential regulation/regional head regulation.

The Budget Implementation Document should have a correlation with the RKA. This is because the ultimate goal of the Budget Execution Document is the achievement of the medium-term development plan of the President/governor/Regent/Mayor during his term of office for 5 years. 


\section{b. Administration of Budgeting}

Administration is carried out by budget users compiled by Regional Apparatus Organizations that handle financial and asset management as financial statements which will be examined by the state auditor, namely the Supreme Audit Agency of the Republic of Indonesia (BPK RI).

c. Budget Execution Accountability

The financial report that has been prepared as material for the examination of the BPK RI records the audit findings that must be followed up on the results of the examination. BPK RI examines the assessment and provides an unqualified opinion; qualified with exceptions; and do not give an opinion. The results of the examination are given to the DPR RI/DPRD to be followed up in a plenary meeting, then determined by regional regulations.

Based on the analysis results from the description above, the manifestation of regional financial management is that the Regional Revenue and Expenditure Budget is an integrated budgeting principle that is integrated with the regional government planning system.

\section{Regional Financial Management, State Finance Subsystem and Main Elements of Regional Government Administration within the Unitary State}

In the form of a unitary state there is no state within a state, there is only one state. So the characteristic of a unitary state is the supremacy of control parliement and absence of subsidiary sovereign bodies. A unitary state is a state that is not composed of several states, but rather a single state. This means that there is only one state and no state within the state, and there is only one government, namely the central government which has the highest power and authority in all fields of government which at the last and highest level can decide everything in the country, including the management of regional finances. which is a sub system of the State financial system.

\section{1.) Regional Financial Management}

Sistem The state financial system is regulated by Law Number 17 of 2003 concerning State Finance. The law regulates the management of regional finances which are part of state finances.

The President as head of government holds the power to manage state finances as part of government power (Article 6 paragraph (1)). Then in paragraph (2); the power as referred to in paragraph (1) is handed over to the governor/regent/mayor as the head of the regional government to manage regional government in the legalized ownership of regional assets (Article 6 paragraph (2) letter c).

The regional head holds the power of regional financial management (PP Number 12 of 2019 concerning Regional Financial Management, article 4 paragraph (1), and in paragraph (3) the power referred to in paragraph (1) is delegated to regional apparatus. In paragraph (4) the apparatus The regions referred to in paragraph (3) are; Regional 
Secretary as coordinator of regional financial management; Head of SKPKD as PPKD; and Head of SKPD/Regional Apparatus Organization as PA.

$A P B D$ as a manifestation of regional financial management has the role of a subsystem of the state financial system because it has been regulated in laws and regulations. Among them is the 1945 Constitution of the Republic of Indonesia Article 1 paragraph (1) which states that; "The State of Indonesia is a unitary state in the form of a republic". Furthermore, in article 18 paragraph (1) it is stated that: "The Unitary State of the Republic of Indonesia is divided into provincial regions, and provincial areas are divided into regencies and cities, each of which has a regional government which is regulated by law.

Article 18A paragraph (1) also explains that the relationship of authority between the central government and regional governments of the Province, Regency/City, and the provincial government is regulated by a law that takes into account the specificity of regional diversity. Article 18a paragraph (2) also explains that financial relations, public services, utilization of natural resources and other resources between the central government and regional governments are regulated and implemented fairly and in harmony based on the law.

2.) The implementation of the State Law of the Republic of Indonesia is regulated in Legislation

Various statutory provisions constituting the implementation of State Finance are at least regulated in the following rules;

a. Law Number 17 of 2003 concerning State Finances;

b. Law Number 25 of 2004 concerning the National Development Planning System;

c. Law number 23 of 2014 concerning Regional Government;

d. Law number 30 of 2014 concerning Government Administration;

e. Government Regulation Number 12 of 2019 concerning Regional Financial Management.

Various theoretical and juridical explanations suggest that the management of regional financial subsystems of the state finances is carried out because in principle there is no state within the state and in a unitary state there is only one government that has the authority and power in deciding the settlement of government, namely the central government. This is based on the Legislation (Laws and Government Regulations in lieu of law in a state of coercion).

In addition to this theory, the laws and regulations also support government relations between the central government and local governments in terms of authority and finances.

\section{3.) Regional Financial Management Basic Elements of Regional Government Administration in a Unitary State}


Regional financial management is realized in an integrated system in regional revenue and expenditure budgets determined by regional regulations. The APBD is prepared annually based on the national development planning system which includes programs and activities of regional government in the context of improving services, empowerment, development and governance. The APBD must be carried out in an orderly manner, obeying the laws and regulations, efficient, economically transparent and responsible by paying attention to a sense of justice and propriety.

APBD has the following functions: First, the Authority Function, the State/regional budget becomes the basis for carrying out revenues and expenditures for the year concerned. Second, the Planning Function. The planning function is intended so that the state/regional budget becomes a guideline for management in planning activities for the year concerned. Third, the Supervision Function. The existence of a supervisory function provides a stipulation that the state/regional budget must always be used as a guide in assessing whether state/regional government administration activities are in accordance with applicable regulations or not. Fourth, the Allocation Function. This function determines that the state/regional budget should be directed at reducing unemployment and wasting resources as well as increasing the efficiency and effectiveness of the economy. Fifth, Distribution Function. This function determines that the state/regional budget must pay attention to the sense of justice and propriety in the administration of state/regional finance. Sixth, Stability Function. This function requires that the state/regional budget be able to be used as a tool to maintain and seek a balance of economic fundamentals.

In order to measure the function of the APBN/APBD, it can be seen in the financial statements which in the end are able to prove the success of government administration. Financial reports on accountability for the implementation of the APBN/APBD audited by BPK RI have an assessment criteria of Fair without exception; Fair with exceptions; and disclaimer. The financial report should have an impact on the success of the Government Agency Performance Accountability System (SAKIP) whose assessment is carried out by the Ministry of State Apparatus Empowerment and Bureaucratic Reform. The indicators used as assessment criteria are; Work Planning; Performance Measurement; Performance Reporting; Internal Evaluation; and Performance Achievements. The criteria carried out have the following assessment :

$\begin{array}{ll}>85-100 & : \text { Satisfying } \\ >75-84 & : \text { Vary Good } \\ >65-74 & : \text { Good } \\ >50-64 & : \text { Enough } \\ >30-49 & : \text { Slightly Less } \\ >0-29 & : \text { Less }\end{array}$

Another tool that can be used to measure the success of state finance is the Human Development Index. Indicators that can be used as benchmarks for the HDI are 
Health; Level of education; and Economics. Besides that, the indicators of the Competitiveness Index are also able to provide an overview of the success of financial management by the Regional Government by looking at environmental indicators; economy; social; and governance.

Integrated regional financial management is realized in the regional revenue and expenditure budget system. The purpose of integrated is that budgeting is based on planning, and in that planning contains programs and activities that accommodate indicators of financial statements, SAKIP, HDI, and IDS as a basis for assessing the success of local governance.

The success of regional government administration is largely determined by an integrated system in regional financial management as a subsystem of state finance in the form of a unitary state.

\section{Conclusion}

Based on the results of the discussion above, it can be concluded as follows: Planning is the first step before implementation which is arranged in 2 ways, namely Bottom Up Planning and Top Down Planning which is carried out in the national and regional development planning system through development planning deliberation from the village/kelurahan level to the national level and planning forums conducted by the Device Organization. Government (Ministries/Institutions), Regional Apparatus Organizations (OPD) produce government activity plans (RKP)/Local Government Activity Plans (RKPD) containing programs and activities that are related to indicators of success in government administration. Budgeting in regional financial management uses an integrated principle (unfield budgeting principle), meaning that there is an integration between state financial management, regional financial management so that there is no overlapping in budgeting, therefore financial management must be orderly, obedient to laws and regulations, efficient, economical. , effective, transparent and responsible by paying attention to the sense of justice and propriety in the management of regional finances that the planning-based budgeting (money follow function) which is realized in the Regional Revenue and Expenditure Budget (APBD) is stipulated by regional regulations. $A P B D$ is an integrated budgeting principle that is integrated into the regional government planning system.

Regional financial management, the subsystem of the state financial system and the main elements of regional government administration in a unitary state, should refer to the concept of the supremacy of the parliament and the absence of subsidiary sovereign bodies. The legislator is only in the central government as the organizer of the state government. Whereas regional government is part of the state government, then in a unitary state, the state is not composed of several countries but the state is singular in nature, there is no state within the state, in a unitary state there is only one government, namely the central government which has the highest authority and power in managing the state. all government activities, including financial management, that regional financial management is a subsystem of the state financial system which is regulated in laws and regulations, regional financial 
management is an integrated system in regional revenue and expenditure budgets stipulated by regional regulations The purpose of being integrated in the budget system Regional income and expenditure is that budgeting must be based on planning which includes programs and activities (money follow function) that accommodates indicators of Financial Statements, SAKIP, HDI, IDSD as a basis for assessing the implementation $\mathrm{n}$ regional government, therefore, the success of regional governance is largely determined by an integrated system in regional financial management as a subsystem of state finances in a unitary state.

As a follow-up to the results of the discussion, in the preparation of regional budgets, revenues and expenditures must be based on indicators of the success of regional government administration. This must be done in order to improve the welfare of the community.

\section{References}

Akmal, Boediyanto, Hukum Pemerintah Daerah-Pembentukan Perda APBD Partisipatif, Putra Media Nusantara, Surabaya: 2010.

Bachrul Amiq, Aspek Hukum Pengawasan Pengelolaan Keuangan Negara dalam Perspektif Penyelenggaraan Negara yang Bersih, LakBang, Pessindo, Yogyakarta, 2010.

Hestu Cipto Handoyo, Hukum Tata Negara, Kewarganegaraan dan Hak Asasi Manusia,Universitas Atmajaya, Yogyakarta, 2003.

Kementerian Keuangan dan Kementerian PPN/Bappenas, Pedoman Reformasi dan Penganggaran, 2009.

Robinson Tarigan, Perencanaan Pembangunan Wilayah, PT. Bumi Aksara, Jakarta: 2005.

Said,Abdul Rauf Alauddin Said."Pembagian Kewenangan Pemerintah Pusat Pemerintah Daerah Dalam Otonomi Seluas-Luasnya Menurut UUD 1945."Fiat Justisia Jurnal IImu Hukum 9, No.4 (2015): 587-602.

Undang-undang Dasar Negara Republik Indonesia Tahun 1945

Undang-undang Nomor 23 Tahun 2014 tentang Pemerintahan Daerah Beserta Perubahannya. Undang-undang Nomor 25 tahun 2004 tTentang Sistem Perencanaan Pembangunan Nasional Undang-undang Nomor 30 Tahun 2014 tentang Administrasi Pemerintahan. 